\title{
Jesuits and Conversos in Sixteenth-Century Toledo
}

\author{
David Martín López \\ University of Castilla-La Mancha, History Department, Ciudad Real, Spain \\ David.MLopez@uclm.es
}

\begin{abstract}
In the early days of the Society of Jesus, the city of Toledo was among the locations where the affinity between the order and the local population of Jewish converts was most patent. Bolstered by members of the most prominent converso lineages, such as the de la Palma and Hurtado families, the order grew exponentially in the final decades of the sixteenth century. Additionally, the Jesuits were active in the controversy surrounding the endorsement of the statutes of purity of blood. They opposed Cardinal Silíceo both directly - by means of their attempts to settle in the city — and indirectly-through their ties with his main detractors in the cathedral council. They also played a prominent role in the memorialist crisis before the eventual approval of the statutes of purity of blood in the Society of Jesus.
\end{abstract}

\section{Keywords}

Society of Jesus - Toledo - conversos - statutes of purity of blood - de la Palma family - Pisa family - Hurtado family - Jerónimo Román de la Higuera

It has long been common knowledge that a special relationship existed between the Society of Jesus and the Jewish converso population, whether because the order welcomed new Christians into its ranks or because the order's critics grossly exaggerated that fact in their campaign to portray the Society as unorthodox and untrustworthy. Indeed, from the early years of its existence, the Society's apostolic and doctrinal approaches were the subject of copious criticism. In particular, the Dominican friars, who maintained various theological disputes and controversies with the Jesuits, cast doubt on the orthodoxy of the early Jesuits' affirmations, despite the major role played by 
Society theologians Diego Laínez (1512-65) and Alfonso Salmerón (1515-85) in the Council of Trent (1545-63).

Such doubts were compounded, among other things, by the Jesuits' defense and development of casuistry, as well as their failure to implement limpieza de sangre (purity of blood) statutes in their recruitment practices, which enabled their attackers to paint the Society of Jesus as a religious order with a questionable background. The success of this strategy was striking, bearing in mind that on more than one occasion the Jesuits were perceived as the cutting edge of Roman post-Tridentine Catholicism. After a series of difficulties and internal controversies, the order approved the statutes at the end of the sixteenth century. According to historian Robert Maryks, several Jesuits suffered discrimination because of their converso origin. ${ }^{1}$

This article seeks to demonstrate that, with regard to the relationship between New Christians and Jesuits, the city of Toledo was no exception. Firstly, the Jesuits had to confront the authority of Archbishop Juan Martínez del Guijo or Silíceo (1486-1557), who would not trust a new religious order that refused to endorse a statute of blood purity; secondly, the Society's ranks swelled thanks to an influx of members of converso lineages, such as the Pisa, de la Palma, and Hurtado families, all of which yielded some of the most outstanding clergymen alive at the turn of the seventeenth century; thirdly, the Jesuits of Toledo played a major part in the long and turbulent process that followed the election of Everard Mercurian (1514-80) as superior general (1573), a process which reached its apex with the anti-converso decree of the Jesuit Fifth General Congregation (1593).

\section{Archbishop Silíceo's Persecution (1547-57)}

News of the Society of Jesus first reached Toledo in 1547, the year in which Archbishop Silíceo obtained approval for application of the purity-of-blood statutes to candidates for positions at Toledo Cathedral. It is documented that several clergymen travelled to Alcalá de Henares that year to do Spiritual Exercises led by Francisco Villanueva (1509-57), the first superior of the Jesuit college there. These early supporters of the Jesuit order were the steward Juan del Rincón (dates unknown) and the priests Sosa (first name and dates

Robert A. Maryks, The Jesuit Order as a Synagogue of Jews (Leiden: Brill, 2010), 117-57. 
unknown), Pinedo (first name and dates unknown), Juan Bautista Sánchez (1525-72), Tomás de Soto (1512-16oo), and Bernal de Venegas (dates unknown). ${ }^{2}$

The latter was one of the links between the Society's beginnings in Toledo and the statutes of blood purity because he was connected to the Zapata family, who led the main faction in the cathedral council opposing the statute. This particular converso family was of great importance in the intermediate decades of the sixteenth century because its members developed an important educational institution based in the cathedral itself. Francisco Álvarez de Toledo Zapata (c.1450-1523) was the cathedral schoolmaster, as well as the driving force behind Santa Catalina College (1485) and the university of Toledo $(1520){ }^{3}$ His successors in office were his relatives Bernardino Zapata (c.14751535), Juan Álvarez de Toledo (1478-1546), Bernardino de Sandoval (?-1572), and Bernardino Alcaraz (1484-1556), who founded San Bernardino University College (1565). ${ }^{4}$ Bernal de Venegas not only assisted the first university rector, Francisco Álvarez de Toledo Zapata (1452-1523), but also was a student, principal (1548-49), and chaplain of Santa Catalina College until he joined the Society of Jesus in $1553 \cdot{ }^{5}$ Little else is known about his life as a Jesuit until his death at the Montilla college. ${ }^{6}$

Venegas was not the only link between the Society of Jesus and the Zapata family. The Jesuits' rapid expansion in Toledo ensured that their paths crossed

2 Although all the individuals mentioned did the Spiritual Exercises, only Soto, Sánchez, and Venegas are documented as having joined the Society of Jesus. Soto, who had an ecclesiastical benefice in the parish of Santo Tomé, lived in the community house in Toledo for over thirty-five years after taking his vows in 1572. Sánchez was rector in Burgos, Orense, and Valladolid until he was posted to Florida as vice-provincial and subjected to martyrdom in 1572. Bartolomé de Alcázar, Chrono-historia de la Provincia de Toledo, 2 vols. (Madrid: Juan García Infanzón, 1710), 1:88; Maureen Ahern, “Dichosas muertes': Jesuit Martyrdom on the Northern Frontier of La Florida," Romance Philology 53, no. 1 (1999): 1-21; Nicholas P. Cushner, Why Have You Come Here?: The Jesuits and the First Evangelization of America (Oxford: Oxford University Press, 20o6).

3 A full biography of this figure may be found in Carmen Vaquero, El Libro de los maestrescuelas (Toledo: n.p., 2007), 13-100.

4 On the evolution of the university's governance by the Zapata family, see David Martín López, Orígenes y evolución de la Universidad de Toledo (1485-1625) (Toledo: Ediciones Parlamentarias, 2014), 59-107.

5 José García Oro and $\mathrm{M}^{\mathrm{a}}$ José Portela Silva, "Santa Catalina de Toledo: De colegio menor a universidad mayor," Liceo franciscano: Revista cuatrimestral de estudio e investigación 16668 (2003): 139-177, here 150-51; García Oro and Portela Silva, "Santa Catalina de Toledo: Seminario y universidad de la iglesia primada de España," Archivo ibero-americano 53, no. 246 (2003): 405-68o, here 437-38.

6 Biblioteca Nacional de España (BNE), MS 1293, Jerónimo Román de la Higuera, Historia eclesiástica de la imperial ciudad de Toledo, fol. $217^{\mathrm{V}}$. 
more than once over the decades. In 1565, Bernardino Zapata bought the Jesuit house of Santo Tomé with the aim of housing San Bernardino College in it. ${ }^{7}$ The proceeds of this sale allowed the Jesuits to move to properties owned by Juan Hurtado de Mendoza, third count of Orgaz (1530-1606), where they lived until their expulsion in 1767 .

The university of Toledo also served as a link between Jesuits and New Christians. Founded by conversos, it was used as a springboard to improve their social standing, ${ }^{8}$ and its professors had close-albeit not always friendly-connections with the Jesuits. Furthermore, in 1561, the aforementioned Bernardino de Sandoval asked the Society to provide grammar tutors for the university, whose classrooms would henceforth be open to the order's scholastics in exchange. ${ }^{9}$ Although we do not know how long these grammar teaching positions lasted, the relationship between the university and the Jesuits was ongoing, as evidenced by the fact that they held a chair of theology at the time of their expulsion in $1767 .^{10}$

Archbishop Silíceo's statute, which included tests of blood purity for access to the ecclesiastical benefits and positions available in Toledo Cathedral, such as dignities, canonries, stewardships, chaplaincies, and altar service posts, caused controversy within the Cathedral Council because it was opposed by converso groups, including, among others, the Zapata family. Although the archbishop was also known for his outstanding efforts to benefit society, such as the foundation of schools for noble boys and girls (colegios de infantes $y$ doncellas nobles), the implementation of a statute of purity of blood and the conflict with the Jesuits showcase the less generous side of his personality. Both events illustrate the conflicting views of the world and society held by Archbishop Silíceo on the one hand, and Ignatius of Loyola (c.1491-1556) and his associates on the other. The former, rising from humble origins, worked hard to reach the top of Spain's ecclesiastical hierarchy. Thereafter, he jealously guarded his position and tried to hinder the rise of the middle echelons of

7 David Martín López, "La Compañía de Jesús en Toledo: Establecimiento y consolidación (1540-1621)" (MA thesis, University of Castilla-La Mancha, 2007), 166.

8 A case in point is Francisco de Pisa, the subject of a forthcoming biography by Francisco J. Aranda Pérez, Toledo circa 1605: La historia-descripción cristianopolitana de Francisco de Pisa (Toledo: UCLM, Antonio Pareja Estudio, in press).

9 Archivum Romanum Societatis Iesu (ARSI), Tolet. 44, doc. 4-5, Fundación de la casa de Toledo, fol. $1^{\mathrm{r}}$; ARSI, Tolet. 44, doc. 2-3, Origen de la casa y colegio de Toledo, fol. $7^{\mathrm{v}}$; ARSI, Hisp. 10o, Epistolae Hispaniae, 1563, "Carta de Juan de Valderrábano a Diego Laínez, de Madrid a 14 de noviembre de 1563," fols. 390 ${ }^{\text {r-v; }}$ ARsi, Hisp. 101, Epistolae Hispaniae, "Carta del padre Juan Manuel a Diego Laínez, de Toledo a 7 de mayo de 1564," fols. $163^{\mathrm{v}}$, $165^{\mathrm{v}}$.

10 Archivo Histórico Nacional (AHN), Consejo Suprimidos, legajo 549o, doc. 1, 3. 
society; ${ }^{11}$ in large part, these strata consisted of conversos who found in religion a means to erase their past and improve their social status. ${ }^{12}$

It is not unusual for the most recent arrival in a place or social group to become the most fervent defender of its status and preserver of its badges of identity. This type of reaction goes a long way to explain the split in the Chapter of Toledo Cathedral. Whereas the city's nobility favored the statute because it would strengthen their position, the conversos opposed it because it would greatly hinder their progress. ${ }^{13}$ In contrast to this kind of social stagnation, the Society favored a more open system based on the notion that every individual was equally deserving of divine grace, an idea discussed by the early members of the order. On the one hand, Loyola did not consider it necessary to implement a statute of blood purity in order to foster Jesuit growth and ensure strong, ever-renewed evangelization. ${ }^{14}$ On the other hand, some of his earliest associates, such as Simão Rodrigues (1510-79) and Antonio de Araoz (151573), held the opposite view, which they expressed in their discussions with Archbishop Silíceo. ${ }^{15}$ At the time, the order's recruitment practice included a trial period and an interview in which the candidate would be asked about his family origins, but under no circumstances would he be rejected as a result of his reply. Instead, his initial rejection or eventual expulsion hinged entirely on his behavior and personal unsuitability for religious life.

The archbishop and the Jesuits also differed in their worldview and their stance on secular leadership. Silíceo stood for the Hispanic-or perhaps solely Castilian - community, and for the defense and increased empowerment of Philip II (r.1556-98) as the champion of Catholic orthodoxy. ${ }^{16}$ For

11 For further information on this matter, see Francisco José Aranda Pérez, ed, Burgueses o ciudadanos en la España moderna (Cuenca: Universidad de Castilla-La Mancha, 2003); Aranda Pérez: Poder y poderes en la ciudad de Toledo (Cuenca: Universidad de Castilla-La Mancha, 1999).

12 Eusebio Rey: "San Ignacio de Loyola y el problema de los cristianos nuevos," Razón y fe 153 (1956): 117-204, here 174 .

13 BNE, MS 732, Copia de la contradicción que hicieron al estatuto [...] algunas dignidades de ella, fol. 144" BNE, MS 5767, Alegato sobre estatuto de limpieza de la Sancta Iglesia de Toledo, fols. $5^{\mathrm{r}}-88^{\mathrm{v}}$.

14 Rey, "San Ignacio de Loyola," 185.

15 Epistolae mixtae, 3:656.

16 A similar conflict arose in the Spanish court between the "Castilian party" and the "Ebolist faction," as can be seen in José Martínez Millán, "La crisis del 'partido castellano' y la transformación de la Monarquía Hispana en el cambio de reinado de Felipe iI a Felipe III," Cuadernos de historia moderna 2 (2003): 11-38; Martínez Millán, "Grupos de poder en la Corte durante el reinado de Felipe II: La facción ebolista, 1554-1573," in Instituciones y élites de poder en la Monarquía Hispánica durante el siglo XVI, ed. José Martínez Millán (Madrid: UAM, 1992), 137-97. 
the archbishop, the Jesuits represented the Roman Church because their additional vow of obedience to the pope. As pointed out by historian Isabella Ianuzzi and demonstrated by events in Toledo, Silíceo had an essentially patrimonial notion of his own office. As a ruler, he acknowledged no superior figure but God; as far as he was concerned, any Jesuit presence in his jurisdiction amounted to papal interference with his authority. ${ }^{17}$ As on several other occasions during the early modern period, the Jesuits were suspected of spying for the pope.

In attempting to implement a statute of purity of blood, Silíceo continued in the footsteps of his predecessor, Juan de Tavera (1472-1545). On July 19, 1547, the Cathedral Council began to debate the statute, which was put to the vote on July 23. Had it been approved, it would have barred the descendants of Jews and Muslims, as well as every person who had been reconciled by the Inquisition, from all positions and benefices in Toledo Cathedral. The converso sections of the council objected to the proposal, and news of their grievance spread beyond the walls of the church, involving Toledo society as a whole in the dispute. Council members belonging to the Zapata family were joined by other clergymen, such as the canons Antonio de León (dates unknown), Esteban Valera (dates unknown), Juan de Salazar (dates unknown), Pedro Sánchez (dates unknown), Dr. Herrera (dates unknown) and Juan de Vergara (1492-1557), who argued that the statute would be detrimental to the institution itself because it would lead to the recruitment of "low, unlettered, and unskilled people."18 The archbishop responded by pointing out that the dissenting families were of Jewish origin, and blamed them for certain events in the city's past, such as the Muslim occupation (c.711-1085), the Revolt of the Comuneros (1520-21), and even the outbreaks of Protestantism that had taken place in recent years. The purpose of the archbishop's claims may have been consolidated his own position by undermining the Zapata family's influence. The Zapata family held several posts in the council and could potentially constitute an ongoing hindrance to his rule. ${ }^{19}$

This vote reflected the conflict among the local nobility at the time. On one side stood the Ayala family, who championed the Old Christians; on the other, the Silva family, who had the support of the conversos. ${ }^{20}$ Silíceo eventually

\footnotetext{
17 Isabella Ianuzzi, "Mentalidad inquisitorial y jesuitas: El enfrentamiento entre el cardenal Silíceo y la Compañía de Jesús," Cuadernos de historia moderna 24 (200o): 167-8o, here 176.

18 Fernando Martínez Gil, "El Antiguo Régimen," in Historia de Toledo, ed. Julio de la Cruz Muñoz (Toledo: Editorial Azacanes, 1997), 257-443, here 305.

19 Martínez Gil, "El Antiguo Régimen," 340; Henar Pizarro Llorente, Un gran patrón en la corte de Felipe II: Don Gaspar de Quiroga (Madrid: Universidad Pontificia de Comillas, 2004), 62.

20 Pizarro Llorente, Un gran patrón, 58.
} 
obtained Pope Paul III's (r.1534-49) support at the end of May 1548, which cleared the way for the statute's implementation in his archdiocese. However, he had to wait until 1556 to receive Philip II's approval; even then, the statute continued to be a bone of contention until the seventeenth century or even later. $^{21}$

While this was taking place, the archbishop of Toledo confronted the Jesuits in his archdiocese directly. Silíceo viewed the group of Toledo clergymen who did the Spiritual Exercises in Alcalá with suspicion. He feared that his archbishopric would be filled with supporters of an order whose orthodoxy was still considered questionable; therefore, he initiated an inquiry into the practice of Spiritual Exercises. Because the resulting reports were, as historian Francisco Antonio put it, "extremely favorable," the archbishop decided to form a committee to study the Exercises, headed by his own nephew. ${ }^{22}$ Aware of his uncle's motives, Diego Martínez Silíceo (dates unknown) tried to ban them in Toledo, despite his description of this Jesuit practice as "holy and good." This attempt met with little success, however, because the large majority of the committee found nothing objectionable in Ignatius's text. ${ }^{23}$ Faced with this outcome, Silíceo responded by buying the land surrounding the building that housed the Jesuit college in Alcalá - the only one the order had succeeded in establishing at the time-so as to prevent the Society's eventual spread across Toledo.

Meanwhile, Toledo's proto-Jesuits set an example of virtue, self-denial, and social conscience across the city, as described by Bartolomé de Alcázar (1648-1721), Francisco Antonio (1535-1610), Juan Eusebio Nieremberg (15951658), and Bernardo de Monzón (16oo-82) in their biographies and eulogies. ${ }^{24}$ The Jesuit pioneers' efforts began to yield results, as the Society was gradually accepted in the city, much to the archbishop's dismay. With the order's expansion into his jurisdiction, Silíceo saw his fears materialize. Matters came to a head when news reached Silíceo that the Jesuits boasted of their ability to act with complete disregard for his authority. ${ }^{25}$ On hearing this rumor, he issued a

21 BNE, MS 1293, Jerónimo Román de la Higuera, Historia eclesiástica de la imperial ciudad de Toledo, fol. $117^{\mathrm{r}-\mathrm{v}}$.

22 Archivo de España de la Compañía de Jesús (AESI-A), C-189, Francisco Antonio, Historia de la Provincia de Toledo, 1:16.

23 Antonio, Historia, 1:17; Alcázar, Chrono-historia, 1:88.

24 Alcázar, Chrono-historia, 1:115-16, 2:65-67; AESI-A, C-189, 2:333; Juan Eusebio Nieremberg, Firmamento religioso de luzidos astros en algunos claros varones de la Compañía de Jesús (Madrid: María de Quiñones, 1644), 706; BNE, MS 5767, Bernardo de Monzón, Menologio de ylustres por todo el orbe y famosos hijos de San Ygnazio..., 1:520.

25 These reports may be biased, since Jesuit historians could have been interested in portraying the Society as overcoming all manner of obstacles, including the opposition of the occupant of Spain's primatial see in Toledo. 
decree, dated October 29, 1551, withdrawing the licenses held by those priests who had done the Spiritual Exercises and banning Jesuits from preaching and administering the sacraments. ${ }^{26}$ Initially, the decree was implemented only in Toledo, but it was eventually applied to the whole archdiocese. Transgression of the decree was punished with monetary penalties and imprisonment, as in the case of Luis de Calatayud (dates unknown), founder of the Ocaña college, who was jailed in 1555 for leaving several donations to the Society of Jesus for the purpose of opening a college. ${ }^{27}$

After the implementation of the decree, Father Francisco de Villanueva and Dr. Miguel de Torres (1505-93), the latter of whom was acquainted with Silíceo, tried to persuade the archbishop to backtrack. However, as accounts of their correspondence make clear, their meetings were cut short as soon as they mentioned the papal bulls confirming the Society's privileges, because the implication was that the Jesuits were only accountable to a higher authority, and therefore such a ban could not apply to them. The archbishop would not countenance such interference from Rome, and was reportedly "incapable of bowing before any superior authority, to the point of claiming that there was no need for a pope here." ${ }^{28}$ Under these circumstances, Villanueva and Torres appealed to the Royal Council, which on November 27, 1551, granted them immunity and barred the archbishop from punishing any person who invoked the bulls of Jesuit privileges. ${ }^{29}$ This did not, however, entitle the Jesuits to preach, confess, or celebrate Mass in the Toledo archdiocese because, as Silíceo pointed out, "the pope did not, by law, have power to provide the Society's men with licenses to preach and confess [...] and if he did so, he was in the wrong and would be told [by Silíceo] that he could not do it." ${ }^{30}$ So, despite his awareness of the Jesuits' papal privileges, Silíceo ignored these privileges and offered to withdraw the decree if and only if the Society agreed to implement the statutes of purity of blood. As mentioned above, this gave rise to a new debate within the order, in which Ignatius's criteria once more prevailed.

26 Pizarro Llorente, Un gran patrón, 63.

27 ARSI, FG 1477, doc. 22-22, Donación del protonotario Calatayud, 16 de octubre de 1555, fols. $3^{\mathrm{r}}-6^{\mathrm{r}}$; ARSI, Tolet. 44, doc. 83 , Relación de la fundación del colegio de la Compañía de Jesús de Ocaña y de sus principios y progreso, fol. $154^{\mathrm{r}-\mathrm{v}}$.

28 Epistolae mixtae, 2:607-10.

29 Joaquín Gil Calvo, La Compañía de Jesús en la historia de Toledo (Toledo: Caja de Ahorro Provincial de Toledo, 1979), 49.

30 AESI-A, C-189, 1:47-48. 
As was often the case in the history of Toledo's Jesuits, they were forced to appeal to the pope for a solution. Cardinal Giovanni Poggi (1493-1556) was charged with mediating and went so far as to advise the Jesuits against making use of papal privileges because it was counterproductive. An interesting feature of this intervention was the exchange in which both parties presented their positions, which highlighted Silíceo's emphasis on Spanishness as opposed to the universality of the Roman church. In reply to the nuncio's petitions, Silíceo asked "to be allowed to oversee his flock," in response to which Poggi demanded that "he leave the Society's men alone, as they are not his sheep." ${ }^{31}$

The Roman curia's support continued to vex the archbishop of Toledo, who realized that he was up against both the crown and the ecclesiastical hierarchy. In addition, the Jesuits continued to attract followers even from within Silíceo's own circle. Bartolomé de Bustamante (1501-70), Cardinal Tavera's former secretary, and Gaspar de Quiroga (1512-94), the archbishop of Toledo from 1577 until 1594, both did the Spiritual Exercises. ${ }^{32}$ Nonetheless, Silíceo was not discouraged, because he still controlled the institutions founded in his archdiocese. He asked several theologians, including the Dominican Melchor Cano (1509-6o), to analyze Ignatius's work in search of errors. The Jesuits, on their part, also sought the support of theologians, such as Bartolomé de Torres (1512-68), Alonso Ramírez de Vergara (dates unknown), and the Dominican Maestro Mancio (c.150o-76). As on previous occasions when Loyola's orthodoxy had been called into question, the reports on his works remained favorable, ${ }^{33}$ but this did not prevent the archbishop-who had become a cardinal in 1555 - from continuing to oppose the Jesuits and their rejection of the statutes of purity of blood until his death in 1557 . Silíceo's demise was not enough to remove the stigma attached to the Society in Toledo, because his supporters took up his critical mantle. The task of clearing the Jesuits' name fell to his successors to the miter, who were more favorably inclined toward the order.

31 Alcázar, Chrono-historia, 1:197; Nieremberg, Firmamento religioso de luzidos, 145. The use of these tropes is interesting, as is the one used by Silíceo himself when he referred to Francisco de Villanueva as a "wolf's head that we have been exhibiting up and down the country to scare off our enemies." Cf. Antonio Astrain, Historia de la Compañía de Jesús en la asistencia de España (Madrid: Sucesores de Rivadeneyra, 1905), 2:105.

32 For further information on these individuals, see Alfonso Rodríguez Gutiérrez de Ceballos, Bartolomé de Bustamante y los orígenes de la arquitectura jesuítica en España (Rome: Institutum Historicum Societatis Jesu, 1967); Litterae quadrimestres ex universis..., 7 vols. (Madrid: A. Avrial, 1895), 2:14-15; Epistolae mixtae ex variis Europae locis ab anno 1537 ad 1556 scriptae (Madrid: A. Avrial, 1899), 2:6o9.

33 Alcázar, Chrono-Historia, 1:212; Nieremberg, Firmamento religioso de luzido, $15^{2}$. 


\section{Jesuits, Conversos, and Toledo Society}

The Jesuits' arrival in Toledo made an impact on local society, which in turn helped the order to settle in the city in the years following Cardinal Silíceo's death. Donations enabled them to support a growing number of members and rent their first buildings in the parishes of San Nicolás and Santo Tomé prior to their permanent relocation to the area near San Ildefonso. Further signs of the Society's impact on the city were the foundation of San Eugenio College in 1583 by Quiroga and the emergence of several citizens' congregations, not to mention the large number of Toledo men who joined the order, although Alcalá de Henares proved to be a more popular choice. ${ }^{34}$ Most of the Society's teaching and management activities were discharged at the Alcalá center until other institutions were able to take on some of these duties. One of these was the Toledo center, which became a professed house within the new province in $1562-65$.

The degree of fragmentation in the sources ${ }^{35}$ and the diversity of the information they offer, especially with regard to the Society's early years, makes it impossible to provide exact figures for the number of Toledo men who entered the order or the locations to which they were assigned. It is, however, possible to assert that at least sixty-seventy people born in the city of Toledo were admitted to the Society of Jesus between 1540 and 1620 . This figure doubles if the range is extended to the territory occupied today by the province of Toledo.

The first generation of Jesuits included some Toledo-born people, such as Alfonso Salmerón (1515-85) and Pedro de Ribadeneyra (1526-1611), as well as the former's brother Diego (d.1545), who died in Padua while still a novice, ${ }^{36}$ and nephew Baltasar (1537-after 1560), who later exchanged the militia Christi

34 For further details of the Society's social expansion process in Toledo, see David Martín López, Religión, poder y pensamiento político: Los jesuitas de la Provincia de Toledo (1540-1621) (PhD diss., University of Castilla-La Mancha, 2016), 243-30o.

The sources referred to are: provincial histories by Alcázar and Antonio; Jerónimo Román de la Higuera's ecclesiastical history of Toledo; Nieremberg's and Andrade's biographical compilations; and the Society of Jesus's administrative catalogs. This last source is very useful for Jesuit studies. Initially, the catalogs were composed of lists of Jesuits organized by houses and provinces. From 1584 on, they provided more information about the Jesuits who lived in each house, including: name, age, place of birth, health, time as a Jesuit, studies, ministries performed, academic degree, and vows in the Society. The catalogs documented the composition of each house for the Roman Curia and were used by superiors to decide upon promotions to positions of responsibility.

36 Pedro de Ribadeneyra, Patris Petri de Ribadeneira, Societatis Jesu sacerdotis: Confessiones, epistolae aliaque scripta inedita, ex autographis, antiquissimis apographis et regestis deprompta, 2 vols. (Madrid: La editorial ibérica, 1920), 1:48. 
for the Catholic King's army by becoming a soldier in $1560 .{ }^{37}$ A number of Toledo men are documented as having joined the Society of Jesus-Dionisio Vázquez (1550), Gaspar Salazar (1552), Alonso de Pisa (1553), Pedro Pablo de Acevedo (1554), and Gaspar Sánchez (1554), among others. The career of the prolific writer Juan de Mariana (1536-1624) helps illustrate the order's development in the city. Born in Talavera in 1536, Mariana spent the last forty years of his life in the Toledo professed house. This became a common pattern over the next few decades, during which Toledo men steadily increased the ranks of the Jesuit order.

The social origin of the new Jesuits varied widely, with members coming from the wealthier segments of the city elite as well as from the more impoverished sectors, including a large number of conversos. As stated above, the sources provide only scant data. Nevertheless, the Jewish origin of certain lineages, such as the Pisa, de la Palma, Hurtado, and de la Fuente families, is readily acknowledged, and several of their members can be found in the ranks of the Society of Jesus. Other individuals belonging to this group may be identified via certain statements in the sources that describe their family origins in terms such as "of honest and virtuous parents" (Gabriel Ordóñez, born in Illescas, 1544-1614); "son of honest and noble parents" (Juan de Peralta, also known as Juan de Goñi, born in Peralta, 1542-88); "son of honest and wealthy parents" (Juan Baptista Sánchez, born in Toledo, 1525-72); "honest and very Christian parents (Tomás de Soto, born in Toledo, 1512-16oo); "honest and not very wealthy parents" (Juan Fernández, born in Toledo, 1538-95); "his parents were honest and some of the most righteous in their village, very Christian and pious" (Juan de Montalvo, born in Villatobas, 1572-?); "very saintly and exemplary parents" (Gaspar Sánchez, born in Ciempozuelos, 1554-1609). ${ }^{38}$ The sheer vagueness of these descriptions stands out in contrast to the detail lavished on the identities of those who were of noble origins or had high-ranking city officials among their kin. It would therefore seem that delving into the

37 Alfonso Salmerón, Epistolae P. Alphonsi Salmeronis (Madrid: Gabrielis Lopez del Horno, 1906), 1:129, 137, 181, 408, 411.

38 Biographical data is extracted from the works mentioned above, i.e. the compilations of renowned Jesuits by Nieremberg and Andrade, and from the eulogies included in the provincial histories by Bartolomé de Alcázar and Jerónimo Román de la Higuera. Nieremberg, Firmamento religioso de luzidos, 9, 27, 680; Juan E. Nieremberg, Vidas ejemplares y venerables memorias de algunos claros varones de la Compañía de Jesús (Madrid: Alonso de Paredes, 1647), 680; Alonso de Andrade, Varones ilustres en santidad: Letras y zelo de las almas de la Compañía de Jesús (Madrid: Joseph Fernández de Buendía, 1666), 629; Alcázar, Chrono-historia, 1:316; 2:331; Bernardo de Monzón: Menologio, 519; Román de la Higuera, Historia eclesiástica, fol. $227^{\mathrm{r}}$. 
ancestry of the former group was not encouraged. It should be noted that, in the above descriptions, parents were praised for being honest, pious, and good Christians. This may be because of the order's youth; it did not have a past to build on, and therefore the collective virtue of its members, always described as irreproachable, wrapped the Society in a halo of sanctity in lieu of illustrious ancestry. In a similar vein, these statements also reflect the concealment of - or at least the failure to state clearly — the ancestry of some of the order's members in order to avoid accusations that they were not Old Christians or, in moral and doctrinal terms, not orthodox and trustworthy. These facts suggest that the descriptions included in the sources that were consulted about the family origins of these Jesuits were part of a project aimed at praising the order and presenting it to society as a religious order that anyone could approach without fear of straying from the righteous path.

We now introduce the life histories of several Toledo-born Jesuits from families known to have been of Jewish origin. The close association between these lineages and the Society of Jesus was not limited to the admission of members of the former into the latter but included other factors as well. For instance, the de la Palma family residence was only a few yards away from the professed house.

This group of Toledan Jesuits from converso families pursued a variety of careers within the Society. Some, such as Luis de la Palma (156o-1641), whose literary works were well-known even outside the order, became highly regarded figures, while others have gone unnoticed even among researchers. In fact, this is the case for the majority of the individuals reviewed below, such as Gaspar de la Fuente, about whom we only know that he joined the Society in 1556 in Alcalá de Henares, took the four vows, studied theology, and served as rector at Arévalo. ${ }^{39}$

Four members of the Hurtado family are documented as having belonged to the Society. Hernando (1559-97) joined as a young man of sixteen and went on to become spiritual coadjutor. At the time of his death, he was rector of the Talavera college. Rodrigo (1544-78) is known to have entered the Society at Salamanca and completed his novitiate at Medina del Campo. After several years at the Toledo professed house, he was one of the missionaries who was sent to preach at Corral de Almaguer (Toledo). He died in Berlanga (Badajoz).

Very little is known about the third brother, Jerónimo (d.1578). He is briefly mentioned by Father Bartolomé de Alcázar as having left the order after a number of years-a longer sojourn than Rodrigo- - to support his mother and sisters, who had fallen into dire poverty."40

39 Alcázar, Chrono-historia, 1:292; Román de la Higuera, Historia eclesiástica, fol. $227^{\mathrm{r}}$.

40 Alcázar, Chrono-historia, 2:564. 


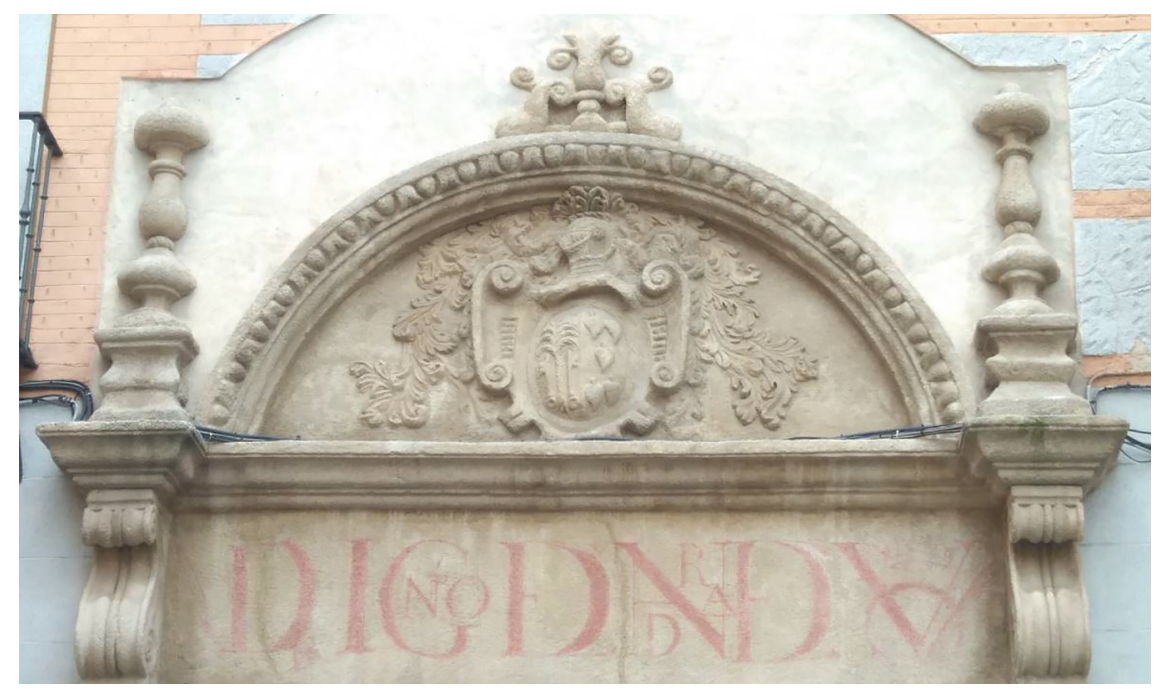

FIGURE 1 Frontage of the de la Palma family home in Toledo SOURCE: AUTHOR'S PHOTOGRAPH

Finally, Melchor (1571-16o8) is the subject of a brief biography kept in the Borbón-Lorenzana repository in Toledo. ${ }^{41}$ He professed as a Jesuit, was a student in the arts, canons, and theology faculties, and died in the town of Arévalo on the Philippine island of Otono. Before traveling to the other side of the world, he stayed in Salamanca, Seville, and New Spain, where he was ordained. He spent almost a decade in the Philippines, evangelizing on several islands, and was taken captive by the Mindanao, Tagalog, and Visayan peoples.

We now turn to Alonso de Pisa (1527-98), brother of the renowned Toledan historian and author of Descripción de la imperial ciudad de Toledo (Description of the imperial city of Toledo, 1605), Francisco de Pisa (15341616). Because a biographical essay on this figure has been published elsewhere, I will not delve into detail here. ${ }^{42}$ His life story is paradigmatic of the lives of early Jesuits, who traveled widely as missionaries and teachers. Also known as "El Pisano," he taught in several schools in Spain, Italy, and

41 Biblioteca de Castilla-la Mancha (вСLм), MS 445, Vida y muerte del venerable siervo de Dios, mártir en el afecto, en los deseos, en la voluntady en los trabajos, [el] Padre Melchor Hurtado, de la Compañía de Jesús, santo mártir en los deseos, que murió a manos de los medios que para ser martyr interpuso en el ejercicio dilatado que tuvo de la predicación y enseñanza del Santo Evangelio y conversión de las almas en el Japón, fols. $123^{\mathrm{r}}-127^{\mathrm{v}}$.

42 Francisco J. Aranda Pérez and David Martín López, "El toledano Alonso de Pisa y Palma, S.I.: 'Apóstol de Posnania' (1527-1598)," in From Ireland to Poland: Northern Europe, Spain and the Early Modern World, ed. Enrique García Hernán and Ryszard Skowron (Madrid: Albatros, 2015), 351-85. 


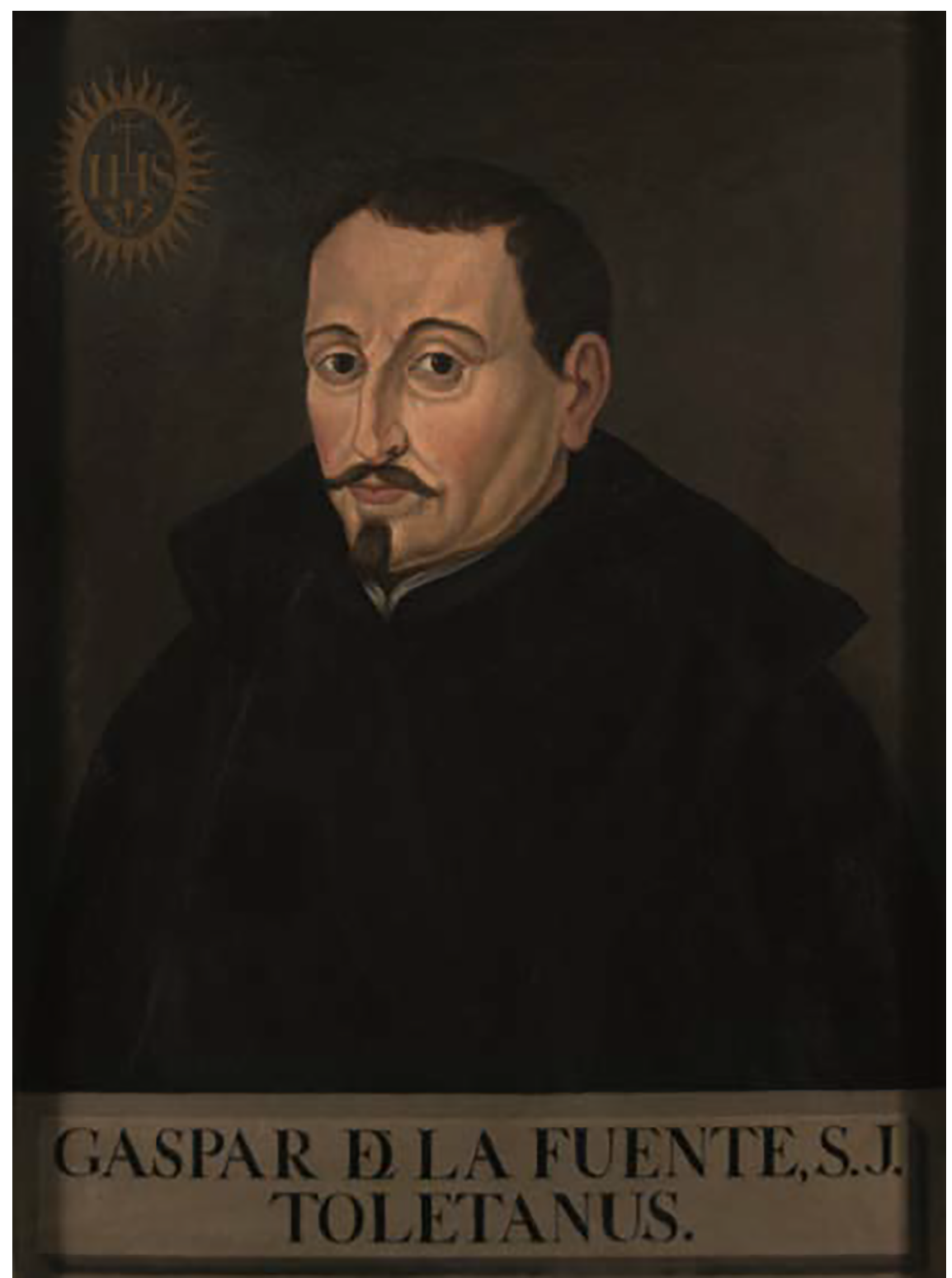

FIGURE 2 Portrait of Gaspar de la Fuente

SOURCE: COURTESY OF THE BiblioteCA DE CASTILlA-LA MANCHA (TOLEDO)

particularly in Central and Eastern Europe, teaching theology and grammar in Ingolstadt, Dillingen, Halle, and Olomuc. In 1577, he went to the recently established Jesuit province of Poland (1574), where he taught at the Kalisz and Poznań schools until his death in 1598. Besides his educational activities, he 


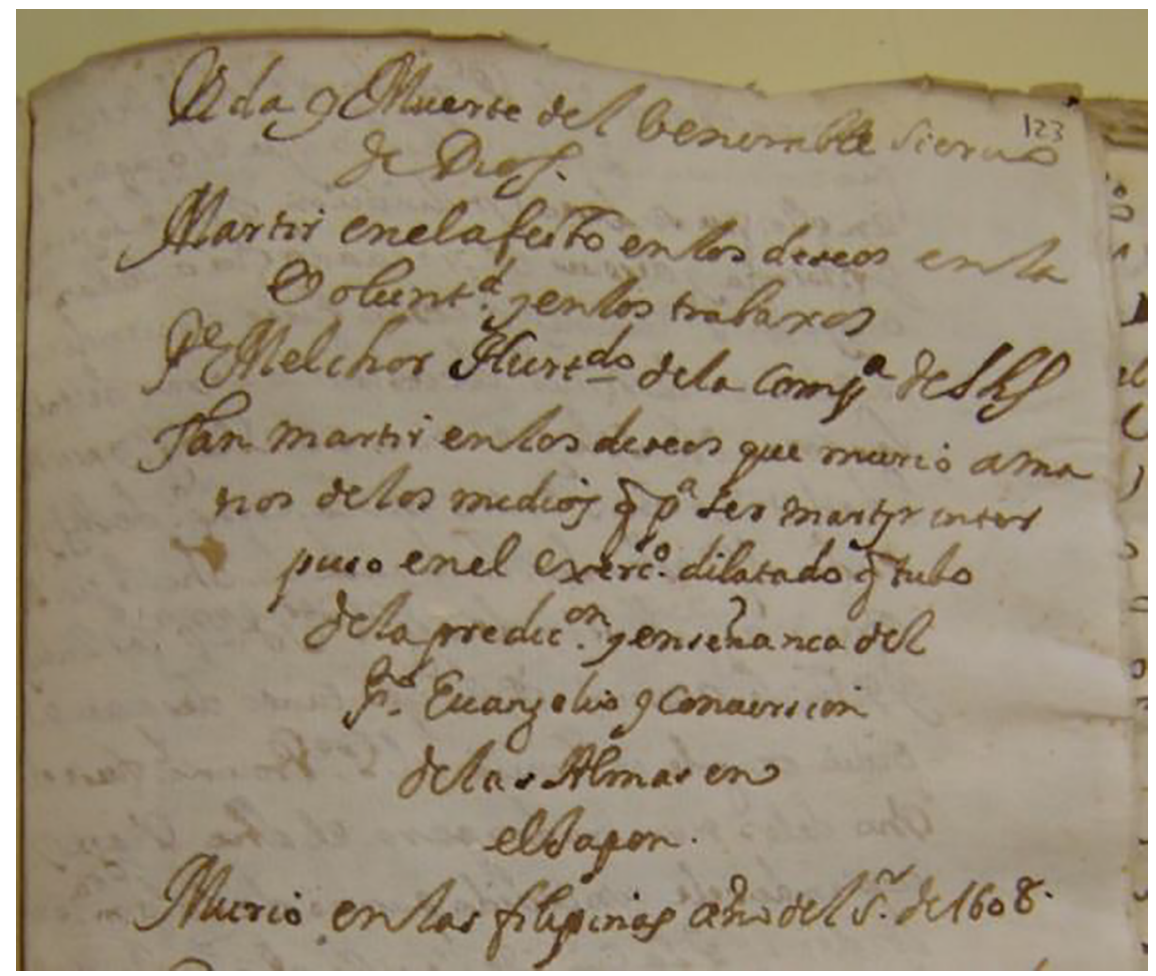

FIgURE 3 "Vida y muerte del venerable [...] Melchor Hurtado," manuscript from the Borbón-Lorenzana repository

SOURCE: COURTESY OF THE BIBLIOTECA DE CASTILLA-LA MANCHA (TOLEDO)

developed an important career as a writer, publishing a number of opuscules on such subjects as religious fasting, diet, abstinence, and celibacy. He also wrote commentaries on several books of the Holy Scriptures and took part in theological debates with central-European Protestants (Jakub Niemojewski, 1532-84; Jakob Andreae Schmidelin, 1528-90; Martin Chemnitz, 1522-86), sometimes as an advisor and sometimes signing the publications himself.

Finally, let us examine the de la Palma family, who lived only a few streets away from the Jesuit professed house. In the period under study, four brothers are known for certain to have joined the Society, with mixed fortunes: Gabriel (1570-94), Hernando (1548-75), Esteban (1564-1636), and the above-mentioned Luis (156o-1641). Additionally, Francisco de la Palma (1585-1654) is said by Jesuit bibliographer Carlos Sommervogel (1834-1902) to have served as rector on three occasions, one of them probably in Belmonte around $1629,{ }^{43}$ but his

43 Carlos Sommervogel, Bibliothèque de la Compagnie de Jésus, 12 vols. (Brussels: O. Schepens, A. Picard, 1895), 6:150. 
possible kinship to the other Jesuits of the same name is not documented. Little is known about the first two. Gabriel studied canon law and died in Huete at twenty-four years of age. ${ }^{44}$ Hernando was a priest in Toledo, where he died in 1575 as a Jesuit novice. ${ }^{45}$

More information is available about Esteban, although he did not achieve the same level of fame as Luis, as we shall see below. He graduated in the arts and studied theology for four years. Once in the Society, he took the four vows, ministered as a preacher and confessor, and fulfilled various administrative posts, such as prefect of studies at Alcalá de Henares and rector of the colleges in Talavera and Toledo, where he spent long periods of his life (1593-97, 161436). He was also in charge of the Annunciata and Niño Perdido congregations. In his fifty-two years as a Jesuit, he wrote several works that met with mixed reception. Although it is mentioned in all the catalogues consulted-Philippe Alegambe (1592-1652), Nathanael Southwell (1598-1676), Nicolás Antonio $(1617-1684),{ }^{46}$ and Sommervogel —it has not been possible to locate a copy of his Memorial de las obligaciones que tiene el hombre christiano, quando se halla con el mal de la muerte (Memorial of the Christian man's duties when faced with the sickness of death), printed in Rome in 1632 and translated into Italian by the Jesuit Francesco Rainaldi (16oo-79). Conversely, the Borbón-Lorenzana repository in Toledo contains two manuscript biographies of women who must have received spiritual guidance from Esteban in his years as superior of St. Eugene's School: Isabel de la Palma (dates unknown) and Ana Sotelo (dates unknown), abbess of Santo Domingo el Antiguo.

Our final figure is Luis de la Palma, the best-known individual in the group. He spent sixty-six years in the order and was a professed father for forty-six of them. He held a variety of posts in the Society across the Toledo province, such as rector in Talavera (1592-96), Alcalá de Henares (16o7-10 and 1630-33), Murcia (1612-14), and Madrid (1618-22 and 1627-29); novice master in Villarejo de Fuentes (16oo3) and Alcalá de Henares/ Madrid (1603-7); provincial inspector in 1599; and provincial for Toledo during two periods (1614-17 and 1624-27). In every one of these posts, he earned an extensive reputation even beyond the Society, thanks to much-repeated stories that praised his treatment of subordinates, particularly novices. He was also a prolific writer, especially in the fields of moral theology

44 AESI-A, 187.5, Alcázar, Chrono-historia, 5:424-28.

45 Alcázar, Chrono-historia, 2:482-83.

46 Philippe Alegambe, Bibliotheca scriptorum Societatis Iesu (Antwerp: Ioannem Meursium, 1643); Nathanael Southwell, Bibliotheca scriptorum Societatis Iesu (Rome: Iacobi Antonii de Lazzaris Varesii, 1686); Nicolás Antonio, Bibliotheca Hispana nova (Madrid: Joaquín de Ibarra, 1783); Sommervogel, Bibliothèque de la Compagnie de Jésus. 
and ascetics, producing such works as Historia de la Sagrada Pasión sacada de los quatro evangelistas (History of the Holy Passion extracted from the four Gospels, Alcalá, 1624); Camino espiritual de la manera que lo enseña el P. Ignacio en su libro de los Exercicios (Spiritual path as taught by Father Ignatius in his book of the Exercises, Madrid, 1626); Práctica y breve declaración del camino espiritual (Practice and brief declaration of the spiritual path, Madrid, 1629); Médico religioso de las enfermedades espirituales y sus remedios (Religious physician for spiritual illnesses and their remedies, Madrid, 1635), which is a translation of Carlo Scribanio's text El exercicio de la muerte (The exercise of death). ${ }^{47}$ There is also his Vida del señor Gonzalo de la Palma (The life of Sir Gonzalo de la Palma), which is a letter to his brother Esteban informing him of his father's death and praising his virtues in the form of a eulogy. This text was preserved in manuscript form until 1879, when it was published by Miguel Mir (1841-1912); since then, it has been reprinted several times, most recently in Camilo María Abad's 1961 edition of de la Palma's complete works, which also includes a number of previously unpublished works - two treatises on the subject of Communion, Meditaciones de la vida y muerte de Nuestra Señora (Meditations on the life and death of our Lady), and a biography of Pedro de Ribadeneyra. ${ }^{48}$

\section{The Statutes of Purity of Blood and the Toledo Memorialists}

Some of the main characters in the controversy known as the "memorialist crisis" were clergymen who lived in the Toledo professed house. After the election of the Society's first non-Spanish superior general, Mercurian, a number of transfers took place among Spanish Jesuits, several of them from Toledo, to locations and posts a long way from Rome and from positions of responsibility. As Maryks has noted, the reason was probably Mercurian's policy of "household cleansing," aimed at keeping conversos at arm's length. ${ }^{49}$ As a result, Ribadeneyra, Mariana, and Dionisio Vázquez (1527-89), among others, returned to Toledo. Vázquez soon began to protest and, together with other Jesuits, signed a number of memorials that were submitted to the king, asking him to arrange for a visitor to examine the Jesuit provinces and reform the Society's customs. ${ }^{50}$ For the purposes of

47 Antonio, Bibliotheca Hispana nova, 57.

48 Camilo M. Abad, ed., Obras completas del Padre Luis de la Palma (Madrid: Ediciones Atlas, 1961).

49 Maryks, Jesuit Order as a Synagogue of Jews, 123.

$5^{\circ}$ For further information on the memorialists, see Martín López, Religión, podery pensamiento político, 215-28; Michela Catto, La Compagnia divisa: Il dissenso nell'ordine gesuitico tra '50o e '6oo (Brescia: Morcelliana, 2009). 


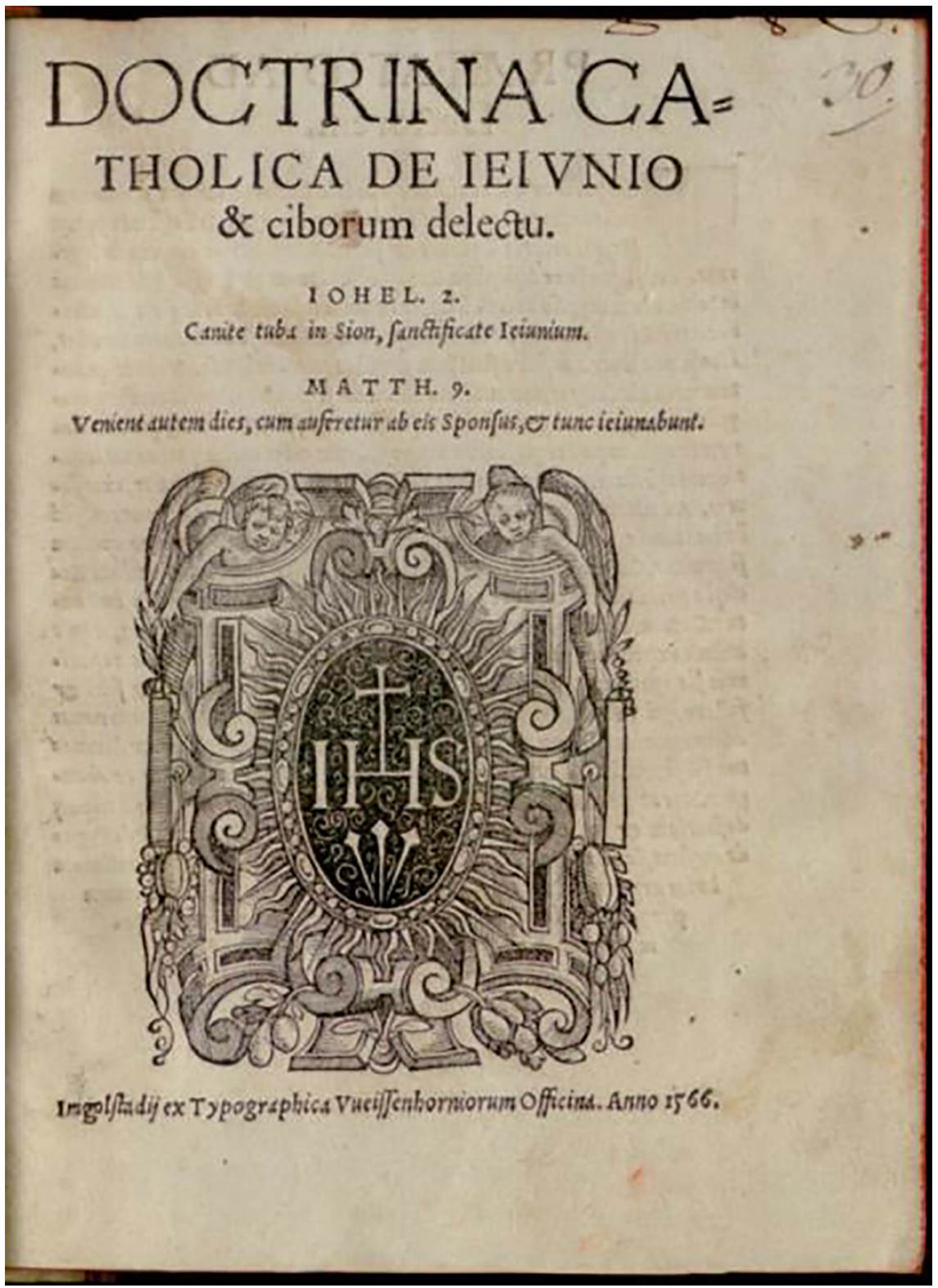

FIgURe 4 Alonso de Pisa: Doctrina catholica de ieiunio \& ciborum delectu (Ingolstadt: Weissenhorn, 1566)

this paper, the main result of their action was a bitter confrontation among Spanish Jesuits that led to the convocation in 1592 of an extraordinary general congregation, over the course of which a statute of purity of blood was finally approved. 


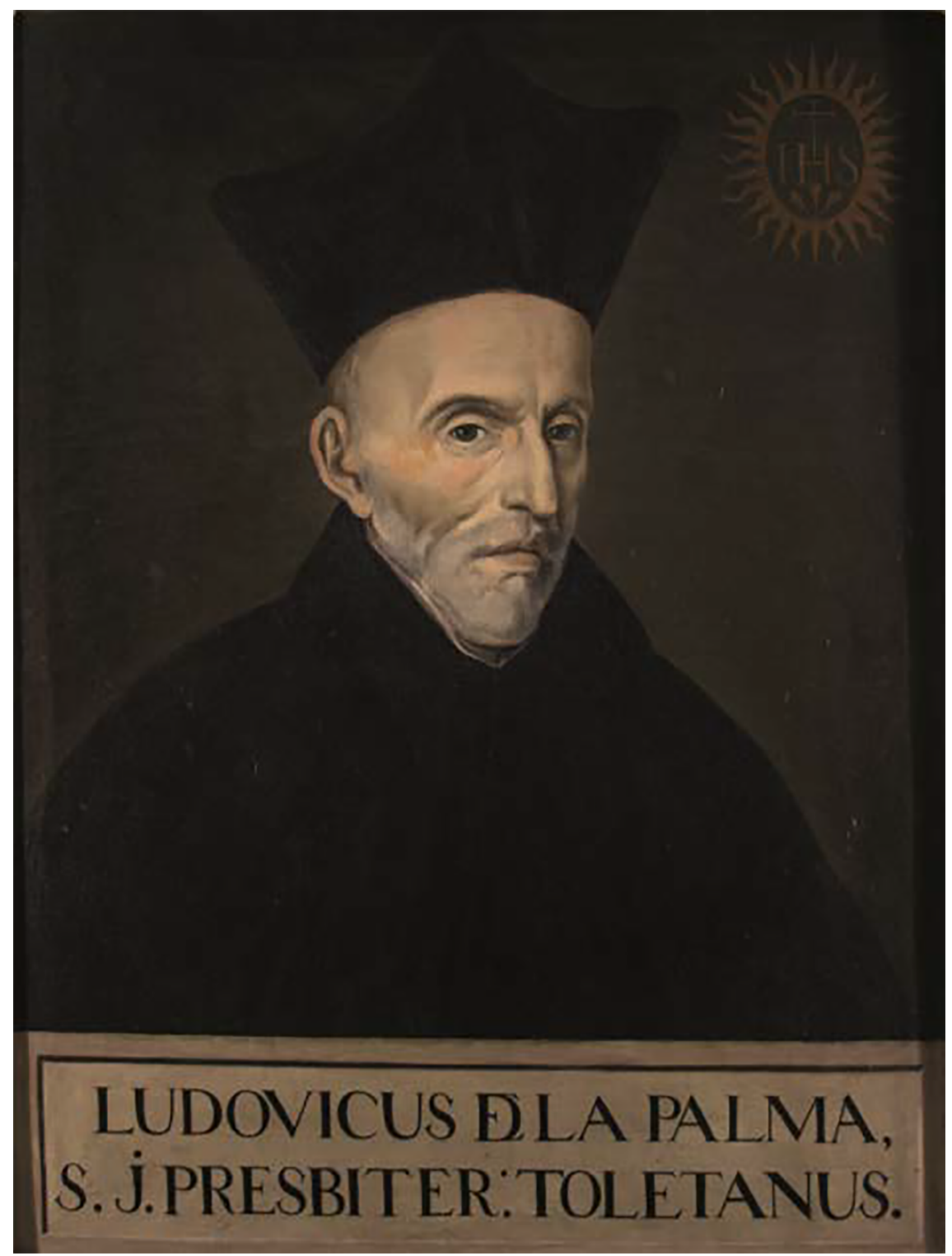

FIgure 5 Portrait of Luis de la Palma SOURCE: COURTESY OF THE BibliotecA DE CASTILla-la MANCHA (TOLEDO)

Toledo Jesuits played an important role on both sides of the confrontation. On the Ignatian side were Ribadeneyra, Diego de Avellaneda (1529-98), and Gil González Dávila (1532-96), who held important posts both in the province and in the city. In the opposite faction, besides the above-mentioned Vázquez, 
were Francisco Abreo (dates unknown), Gaspar Sánchez (dates unknown), Luis de Mendoza (dates unknown), ${ }^{51}$ Juan Osorio (dates unknown), and Antonio Veruete (dates unknown), who had been sacristan's assistant in the professed house and was expelled around the time of the controversy. ${ }^{52}$ Some researchers include Mariana in this faction on account of his Discurso sobre las enfermedades de la Compañía (Discourse on the Society's diseases), but his involvement in these incidents remains uncertain.

The memorialist crisis did not end in 1593. The Society continued debating the point over the years to follow, as is substantiated by Antonio Ramiro's (1540-16o9) correspondence with Rome. In his letters, Ramiro spelled out the uncertainty and confusion created by the statutes. First and foremost, he questioned whether the congregation was the right place to discuss such matters, as the likely result would be to exclude potential Spanish candidates from the position of superior general. He goes on to warn of the undesirable consequences of "excluding those without a lineage," arguing that it would cause derision, major disagreement, and even false testimony, as well as hamper the Society's necessary intake of members to fill its ministries and foundations. ${ }^{53}$

\section{Román de la Higuera: Historian and Genealogist}

The debate then lay dormant for a few years, only to flare up again in 1608 , with Toledo playing a major role in a conflict that once again resulted in an extraordinary general congregation. On this occasion, the finger was pointed at the controversial Jerónimo Román de la Higuera (1538-1611), who several years earlier, before the Inquisition, had filed a suit against Pedro de Carvajal (dates unknown), vice-rector and prefect of studies at the Ocaña college. ${ }^{54}$ The issue in this case was not so much the statutes, but a host of other matters concerning hierarchy, membership, and governance.

The lawsuit itself illustrates the kind of relationship that existed between Father Higuera and his superiors, and his interactions with other prominent figures in the final years of his life. Both the legal proceedings and Olavide's article on the issue suggest a certain resentment on Higuera's part toward his superiors, which came to a head with their refusal to print his Historia de la

51 BNE, MS 12804, El P. Francisco de Abreo de la Compañía de Jesús al Consejo de Inquisición, 245.

$5^{2}$ BNE, MS 12804, Antonio Veruete de la Compañía de Jesús, al obispo de Cartagena, 282; AESI-A, "Trienial catalogue for the Toledo province," 1587 , Toledo professed house.

53 ARSI, Tolet. 37a, Letter from Antonio Ramiro, November 3, 1597, fols. $295^{\mathrm{r}}-298^{\mathrm{r}}$.

54 Ignacio Olavide, "La Inquisición, la Compañía de Jesús y el P. Jerónimo Román de la Higuera," Boletín de la Real Academia de la Historia 42 (1903): 108-9, 118-19. 
imperial ciudad de Toledo (History of the imperial city of Toledo), which is preserved in manuscript form at the Biblioteca Nacional de España (BNE). Higuera was shocked to see that the provincial congregation authorized and published, among others, Historia de España (History of Spain) and the controversial De rege et regis institutione (Of king and the institution of kingship) by Juan de Mariana; all of Ribadeneyra's works, except his history of the Spanish and American provinces, which was approved in 1611 but never went to press; 55 and Luis de la Palma's Meditaciones (Meditations), which were approved for printing in 1604 and $1606 .{ }^{56}$

Higuera's works, on the other hand, were rejected, despite Rome's judgment, delivered by Father Gabriel de Vega (1550-1619) in 1606, that "they should be seen and, having been found worthy of the press, printed."57 The report issued on the subject has not survived, but it is easy to infer that his reputation for deceit and the 1604 lawsuit did not help his cause. Yet, this stands in stark contrast to the reception of his writings among the Society's historians: both Bartolomé de Alcázar and Francisco Antonio, authors of histories of the Toledo province, included him among their sources.

Father Higuera is best known for the creation of false chronicles, as reported by historiographers since the seventeenth century. ${ }^{58}$ His fabrication of supposedly paleo-Christian documentary sources forever cast his entire body of writings into doubt. Although this is not the place to explore Higuera's work in detail, I would like to argue in his favor by pointing out that not all of his historiographical production is based on dubious evidence. Some of his narratives set in remote times - such as the stories in Flavio Dextro — must obviously be dismissed, as they are likely based on falsehoods. However, his works also include a history of Toledo and a history of the Jesuit college in Plasencia, ${ }^{59}$ which are used to this day by historiographers as sources of information for events that occurred in the sixteenth century, many of which were witnessed by Higuera himself. Similarly, his manuscript on the different families and lineages of

55 ARSI, Congr. 53, fol. $65^{\mathrm{r}}$.

56 ARSI, Congr. 49, fol. 80 ${ }^{\mathrm{v}}$; ARSI, Congr. 51, fol. $95^{\mathrm{v}}$.

57 ARSI, Congr. 51 , fol. $84^{\mathrm{r}}$.

$5^{8}$ Evidence of this may be found in BNE, MS 7364, Nicolás Antonio, Defensa de la historia de España contra el P. Higuera; José Godoy Alcántara, Historia crítica de los falsos cronicones (Madrid: M. Rivadeneyra, 1868); José Martínez de la Escalera, "Jerónimo de la Higuera S.J.: Falsos cronicones, historia de Toledo, culto de san Tirso," in Tolède et l'expansion urbaine en Espagne (1450-1650) (Madrid: Casa de Velázquez, 1991), 67-97; Katrina B. Olds, Forging the Past: Invented Histories in Counter-Reformation Spain (New Haven: Yale University Press, 2015).

59 AESI-A, C-222, Jerónimo Román de la Higuera, Historia del Colegio de Plasencia de la Compañía de Jesús. 
Toledo, dated around $1602,{ }^{60}$ continues to be a valued source among genealogists. This wide-ranging manuscript lists the origins of various Toledo families, including several Mozarabic lineages (Palomeque, Cervatos, Gudiel, Armilde), and a number of families that stand out because of their connection to the Society of Jesus and its consolidation in the Toledo urban landscape, such as the Barroso, Meneses, Azevedo, Gaytanes, and Ribadeneyra lineages, as well as the house of Hernán Dálvarez de Toledo. ${ }^{61}$

\section{Conclusion}

In this article, I have sought to show the close relationship between the converso population and the Society of Jesus in sixteenth-century Toledo, and its expression in various events that took place in the city. The Jesuits' strong opposition to Cardinal Silíceo's statutes of purity of blood, together with their ties to some of the latter's enemies in the cathedral council, was followed, several decades later, by the memorialist crisis, with flare-ups taking place in Toledo and its provinces between 1580 and 1610 . One of the consequences of this crisis was the Society's acceptance of a statute of blood purity.

The writer Jerónimo Román de la Higuera stands out among the clergymen who may have contributed to the memorials that were sent to the king. Although Román de la Higuera has gone down in history for his documentary forgeries, some of his texts have been found to have a sound documentary basis and are used as sources by researchers to this day.

The relationship between the Society of Jesus and New Christians was by no means entirely negative or critical; on the contrary, we have identified several converso families in Toledo that provided the order with numerous novices, such as the Pisa, Hurtado and, in particular, de la Palma families, which were also highly interconnected. Since the Jesuits did not require proof of purity of blood from their candidates in its first four decades, a close relationship developed between these families and the Society. These ties with local families were instrumental in the consolidation of the order in the city, after many years of conflict with Archbishop—-later Cardinal—Silíceo, and would help to enable the Jesuits' continued expansion in Toledo society during the seventeenth and eighteenth centuries until their expulsion from the Spanish territories in $1767 .^{62}$

6o BNE, MS 3302, Jerónimo Román de la Higuera, Linajes de Toledo.

61 Martín López: Religión, podery pensamiento político, 243-30o.

62 This article has been financed by the European fund for regional development (reference: 2019-GRIN-27063). 